\title{
Size and Skeletal Variation in Male Bank Vole Along an Altitudinal Gradient in Western Norway
}

\author{
Christian OTTO
}

\begin{abstract}
Otto C., 1978: Size and skeletal variation in male bank vole along an altitudinal gradient in western Norway. Acta theriol., 23, 25: 391-399, [With 3 Tables].

Size showed significant differences along the altitude gradient, and the largest bank voles, Clethrionomys glareolus (S ch re be r, 1780), were found at an intermediate altitude where density also peaked. Individual skeletal variants did not show any uniform pattern of variation, but the overall estimate of divergence increased successively from sea level to treeline.
\end{abstract}

[Zool. Museum, Muséplass 3, N-5014 Bergen/Univ., Norway].

\section{INTIRODUCTION}

Regional variation in size and pelage traits in the bank vole (Clethrionomys glareolus $\mathrm{S}$ c h r e b e $\mathrm{r}, 1780$ ) has lead to the recognition of a number of subspecies. Thus Miller (1912) regarded the form of bank vole in western Norway as a distinct subspecies, while S t e v e n (1952) considered it to be identical with those of the rest of Scandinavia. In Great Britain four insular populations were each assigned species value by Barrett-Hamilton \& Hinton (1913 a, b), but Steven (1955) and $\mathrm{C}$ or bet (1964) considered them as "good subspecies". C or bet (1964) also regarded the British mainland form as belonging to the same subspecies as the form in Denmark and north France. As to the European mainland, Haitlinger (1970) concluded that new subspecies have been described from every higher mountain range. The regional differentation of external characters of the bank vole suggest a high potential of covert variation within as well as between populations, as has been demonstrated for mice (genera Apodemus and Mus) by B e r r y (1970, 1973).

Minor skeletal variants constitute a spectrum of natural variation in species that have been studied so far. The occurence of these variants depends partly on the individual's genetic make-up and partly on a number of non-genetic factors (B erry \& S e a r le, 1963). The works by $\mathrm{Gr}$ ü ne ber g (1951) and S e a r l e (1954) clearly demonstrated, that a threshold mechanism (e.g. maternal diet) was involved in this type of variation. To separate this kind of discontinuous variation, that was 
not determined at fertilization but at some later stage in development, from true polymorphism, Berry \& Searle (1963) called it »epigenetic polymorphism«. Gr ün e b e r g (1963) considered that each variant being an expression of epigenetic polymorphism. was dependent of several loci, and that every locus affected several variants. B e r r y \& J a cobsen (1975) suggested each variant to be under control of at least 10 loci. The variants were accepted as expressions of the genetical constitution of an individual ( $\mathrm{B}$ e r r y, 1963), and they have often been used to estimate the divergence of populations (e.g. B e r r y, 1973, B e rry \& Warwick, 1974, S jøvold, 1977).

The present study was devoted to the variation in external characters such as body size and pelage colour as well as the variation in nonmetrical skeletal traits in C. glareolus along an altitudinal gradient ranging from 0 to $750 \mathrm{~m}$ a.s.1.

\section{STUDY AREA}

Animals were trapped in the Eksinge valley (approx. $60^{\circ} 50^{\prime} \mathrm{N}, 6^{\circ} 15^{\prime} \mathrm{E}$ ) about $130 \mathrm{~km} \mathrm{NE}$ Bergen from April through July 1977. The valley, which approximately slopes in an east-west direction, is about $35 \mathrm{~km}$ long and starts at sea level and reaches an altitude of about $800 \mathrm{~m}$ a.s.1. in the easterly part, which coincides with the treeline. The mountains surrounding the valley reach an altitude of $800-1000 \mathrm{~m}$. The slopes of the valley are steep, and they often consist of bare rooks.

Four stations at $0,300,600$ and $750 \mathrm{~m}$ a.s.l., respectively, were selected for trapping, and they will be reffered to as station $A, B, C$ and $D$, respectively. The horizontal distance (excluding altitudes above $800 \mathrm{~m}$ ) between station $A$ and $B$ was $17 \mathrm{~km}, B$ and $C 15 \mathrm{~km}$ and $C$ and $D 3 \mathrm{~km}$ respectively. Each station comprised of an area with a diameter of about $1 \mathrm{~km}$. The most conspicuous tree species were: at station A Corylus avellana L., and Betula pubescens Ehrh., at B Picea abies (L), B. pubescens, Alnus incana (L), and Prunus padus (L.), at C P. abies and B. pubescens, and at $D$ bushes of Salix sp. and B. pubescens: At station $A, B, C$; and $D$ snow covered the ground for about $4,5,6$ and 7.5 months, respectively.

\section{MATERIAL AND METHODS}

Small mammals were trapped in live traps ("Owl Special «), which were baited with rolled oats. The traps were inspected at daily intervals, and the number of trap-nights per station usually ranged between 100 and 400 per month. At station $D$ no trapping took place until the last days of May. Immediately after the animals were killed they were sexed, body- and tail-length were measured to the nearest $\mathrm{mm}$, hind-foot to the nearest $0.5 \mathrm{~mm}$, and they were weighed to the nearest $\mathrm{g}$. In the laboratory males born in the year before were skinned, and the carcasses were enzymatically macerated with trypsine.

After maceration the condylobasal length (excl. nasale) and the zygomatic width of the skulls was measured to the nearest $0.1 \mathrm{~mm}$. The presence or absence of the skeletal variants listed in Table 3 was recorded. Out of these variants nos $1-20$ 
were related to the skull, while no 21 concerned a foramen of the pelvic girdle. The nomenclature for most of the variants followed that used by Berry (1963) for house mouse (Mus musculus L.), although the exact position of the variants differred slightly. Variants nos $1-4,10-12$ and $18-21$ were synonymous to those used by Berry (1963). Variant no 5 "lower frontal foramen double « concerned a large foramen situated below the ordinary frontal foramen, and it was sometimes divided into two. Interparietale of these bank voles were covered by several small foramina, and in some cases one of these foramina was large compared to the others and when seen without magnification, it was termed »interparietal foramen large» i.e. wariant no 6. Variants nos 7 and 8 concerned foramina situated just superior and inferior, respectively, to the processus of the quadratum bone, and these foramina sometimes were double. Variant no 9 consisted of a bridge of the palatinum bone behind the foramen palatinum majus, and this bridge was sometimes open. Variant no 13 consisted of two small foramina situated laterally on the posterior part of the presphenoid bone. Variant no 14 was synonymous to one used by Berry (1963), but the position of the two processuses in bank vole was much closer to each other than in house mouse. Variant no 15 was synonymous to one used by Steven (1953) for C. glareolus, and he divided the last upper molar into simple and complex forms depending on the absence and presence respectively of a fourth loop on the inner surface of the third upper molar. Variants nos 16 and 17 both concern foramen ovale. Berry \& S earle (1963) demonstrated the great variation in shape of foramen ovale between as well as within species. In the present study foramen ovale always had the basic separation into a double foramen, but sometimes the posterior part was bridged into two resulting in a wforamen ovale treble (variant no 16). Outside the bridge dividing foramen ovale into two, a second bridge was sometimes present resulting in a foramen perpendicular to the former ones, and this bridge was called »bridge outside foramen ovale " (variant no 17). The percentage frequences of the bilateral variants given in Table 3 were based on the number of sides on which the variant occurred. In a few calculations damage to a specimen made the total less than indicated by $n$.

The pelage colour of the ventral side was compared with Munsell colour standards (M unsell, 1947), and the results were expressed as the percentage frequency of pelages of maximum colour strength (chroma) observed (variant no. 22 in Table 3).

To estimate the divergence for any individual variant between two different stations ( 1 and 2) listed in Table 3 the following formula, developed by Berry (1963), was used: Estimate of divergence (E. D.) $=\left(\Theta_{1}-\Theta_{2}\right)^{2}-\left(1 / n_{1}+1 / n_{2}\right)$ where $\Theta$ is the angular transformation in radians of the percentage frequency of a variant in the sample, and $\mathrm{n}$ is the number of specimens scored. The angular value $\Theta$ corresponding to the percentage incidence $p$ was defined by: $\Theta=\sin ^{-1}(1-2 p)$. A multivariate "measure of divergence " to give an estimate of the distance between two samples is obtained by taking the mean of the measures for individual variant comparisons.

\section{RESULTS}

As seen in Table 1 C. glareolus was the only small mammal species trapped at all four stations investigated. Trapping was also performed at higher altitudes, but no bank voles were obtained. The highest number 
of species were found at the intermediate stations, while the number declined both towards the sea and at the treeline. It should be noted, that no lemmings (Lemmus lemmus L.) were taken in the traps, but they were observed (dead and alive) at the three uppermost stations. The density of $C$. glareolus in terms of males caught in this study was $0.05,0.11,0.05$ and 0.01 per trap night at station $A, B, C$, and $D$, respectively.

The analyses of the metrical variation in male bank vole (Table 2) showed, that the overall size in terms of weight declined significantly from station $B$ to $C$. For hind-foot and tail/body length no significant difference between station $B$ and $C$ or $B$ and $D$ was found. Skull width reached a peak value at $B$, while significantly lower values were observed in both directions. Skull length also was longest at $B$, but it was

Table 1

Relative abundance $(+,++,+++)$ of small mammals in relation to altitude in the Eksinge valley, western Norway.

\begin{tabular}{|c|c|c|c|c|}
\hline Altitude (m a.s.1.) & 0 & 300 & 600 & 750 \\
\hline $\begin{array}{l}\text { Sorex araneus L. } \\
\text { Sorex minutus L. } \\
\text { Lemmus lemmus (L.) }\end{array}$ & + & $\begin{array}{r}++ \\
+ \\
+\end{array}$ & $\begin{array}{r}++ \\
+ \\
+\end{array}$ & $\begin{array}{r}+ \\
++\end{array}$ \\
\hline $\begin{array}{l}\text { Clethrionomys glareolus } \\
\text { (Schreb.) }\end{array}$ & ++ & ++ & ++ & 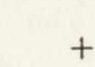 \\
\hline Microtus agrestis (L.) & + & +- & ++ & \\
\hline Microtus oeconomus (Pal & & & + & +++ \\
\hline Apodemus sylvaticus L. & ++ & +++ & + & \\
\hline
\end{tabular}

only significantly longer when compared to a higher altitude, and the same held for the width/length relationship of the skull.

The non-metrical skeletal variants (Table 3) did not show any uniform pattern of variation. Some variants reached peak values at $A$ and $D$ respectively, while other peaked at the intermediate stations. The pelage colour measurements of the ventral side all fell within the same hue (10 YR), and the value, which was a measure of lightness, was almost identical at the four stations. The colour strength (chroma) varied between 1 and 4 , and at station $B$ chroma 4 was most frequent compared to the other stations (Table 3 ), while chroma 1 showed the opposite pattern variation.

The estimate of divergence between the four stations (Table 4) was highest when station $A$ and $D$ was compared, while the lowest value was obtained between $C$ and $D$. Thus the greatest divergence coincided with the greatest horizontal and vertical distances between the stations. 
Table 2

Metrical variation in male bank vole in relation to altitude. $\mathrm{n}$ denote number of animals. $P$ values calculated by $t$-test.

\begin{tabular}{|c|c|c|c|c|c|c|c|c|c|c|c|}
\hline \multirow[t]{2}{*}{ Altitude (m a.s.1.) } & \multicolumn{2}{|c|}{$\begin{array}{c}0 \\
n=48\end{array}$} & & \multicolumn{2}{|c|}{$\begin{array}{r}300 \\
n=65\end{array}$} & \multicolumn{4}{|c|}{$\begin{array}{r}600 \\
n=42\end{array}$} & \multicolumn{2}{|c|}{$\begin{array}{r}750 \\
n=6\end{array}$} \\
\hline & $\overline{\mathbf{x}}$ & S.E & & $\overline{\mathbf{x}}$ & S.E & & $\overline{\mathbf{x}}$ & S.E & & $\overline{\mathbf{x}}$ & S.E \\
\hline Weight (g) & 27.7 & 0.52 & N.S. & 28.1 & 0.43 & $0.02<P<0.05$ & 26.8 & 0.45 & N.S. & 25.5 & 1.23 \\
\hline Hind-foot $(\mathrm{mm})$ & 18.45 & 0.07 & N.S. & 18.58 & 0.06 & N.S. & 18.43 & 0.07 & N.S. & 18.33 & 0.11 \\
\hline Tail-/body-length & 0.426 & 0.004 & N.S. & 0.428 & 0.003 & N.S. & 0.424 & 0.003 & N.S. & 0.423 & 0.004 \\
\hline Skull width (mm) & 14.33 & 0.05 & $0.02<P<0.05$ & 14.57 & 0.04 & $P<0.001$ & 14.35 & 0.05 & N.S. & 14.13 & 0.10 \\
\hline Skull length (mm) & 25.78 & 0.08 & N.S. & 25.85 & 0.07 & $P<0.001$ & 25.22 & 0.07 & N.S. & 25.50 & 0.22 \\
\hline Skull width/length & 0.560 & 0.002 & N.S. & 0.564 & 0.001 & $0.01<P<0.02$ & 0.569 & 0.002 & $0.001<P<0.01$ & 0.554 & 0.005 \\
\hline
\end{tabular}




\section{DISCUSSION}

Size variation in terms of weight, skull length and width showed significant differences between the stations. The largest specimens were found at station $B$, and this coincided with a relative population density about twice as high as that at stations $A$ and $C$. In bank vole size diffe-

\section{Table 3}

Non-metrical skeletal variation in male bank vole in relation to altitude expressed as per cent of the total in each station. The variants indicated by + are single ones while the others are bilateral. $\mathrm{n}$ denote number of animals.

\begin{tabular}{|c|c|c|c|c|}
\hline $\begin{array}{l}\text { Altitude (m a.s.l) } \\
\text { Variant }\end{array}$ & $\stackrel{0}{n}=48$ & $\begin{array}{c}300 \\
n=65\end{array}$ & $\begin{array}{c}600 \\
n=42\end{array}$ & $\begin{array}{c}750 \\
\mathrm{n}=6\end{array}$ \\
\hline 1. Preorbital foramen double & 20 & 4 & 2 & 0 \\
\hline 2. + Parted frontals & 0 & 0 & 0 & 0 \\
\hline 3. + Frontal frontanelle present & 0 & 0 & 0 & 0 \\
\hline 4. Frontal foramen double & 41 & 44 & 23 & 33 \\
\hline 5. Lower frontal foramen double & 10 & 14 & 19 & 0 \\
\hline 6. + Interparietal foramen large & 19 & 10 & 12 & 17 \\
\hline 7. Superior quadratum foramen double & 0 & 6 & 4 & 0 \\
\hline 8. Inferior quadratum foramen double & 25 & 19 & 6 & 8 \\
\hline Palatinum bridge open & 5 & 20 & 37 & 58 \\
\hline Maxillary foramen I absent & 23 & 29 & 44 & 58 \\
\hline 11. Maxillary foramen II absent & 4 & 13 & 6 & 8 \\
\hline 12. + Foramen sphenoidale medium present & 23 & 34 & 26 & 0 \\
\hline 13. Foramen sphenoidale laterale present & 45 & 48 & 39 & 17 \\
\hline Processus pterygoideus present & 28 & 13 & 37 & 8 \\
\hline Third upper molar simple & 100 & 100 & 100 & 100 \\
\hline Foramen ovale treble & 2 & 2 & 1 & 0 \\
\hline Bridge outside foramen ovale & 0 & 0 & 7 & 0 \\
\hline Foramen hypoglossi double & 56 & 42 & 51 & 83 \\
\hline Accessory mental foramen & 20 & 24 & 8 & 0 \\
\hline Third lower molar present & 100 & 100 & 100 & 100 \\
\hline 21. Foramen acetabuli non-perforans present & 88 & 87 & 68 & 83 \\
\hline 22. + Chroma 4 & 6 & 22 & 9 & 17 \\
\hline
\end{tabular}

Table 4

Estimate of divergence between the four stations. A negative value means that the samples are statistically indistinguishable, and the higher the value is the greater is the divergence.

\begin{tabular}{cccc}
\hline Station & $A$ & $B$ & $C$ \\
\hline$D$ & 0.125 & 0.030 & 0.020 \\
$A$ & & 0.045 & 0.080 \\
$B$ & & & 0.050 \\
\hline
\end{tabular}

rences seemed to be determined genetically (S t e ve n, 1953), and at station $B$ a high relative density might put a selective premium on large size as compared to the other stations. This would be in accordance with the suggestion by Corbet (1961), that intraspecific selection favour 
large size. At: station $B$ also $A$. sylvaticus, that species of those present which occupied a habitat most similar to that of $C$. glareolus, was most common. Thus the possible advantage of large size in interspecific interactions should not be neglected. The importance of size for the outcome of intra as well as interspecific interactions in Microtus pennsylvanicus Ord and Clethrionomys gapperi Vigors was demonstrated by M c E $1 \mathrm{~m}$ a $\mathrm{n}$ \& M orris (1977), but previous experience during intraspecific interactions also seemed to be of great importance.

The present finding, that size declined towards the tree line, was contrary to expectation from the point of view of Bergman's rule. In Poland on the other hand $\mathrm{H}$ a it linger (1970) found that bank voles from mountain populations were distinctively larger than those from lowland populations. Regarding tail/body-length relationship as a relevant expression with respect to Allen's rule, neither this rule was supported by the present findings in terms of significant differences, although the relationship declined from station $B$ to $D$.

The estimates of divergence between the stations showed, that in terms of skeletal variants discrete genetic differences occurred between demes of the bank vole population inhabiting the valley. Although a certain amount of gene flow possibly occurs over the mountains, since young individuals may spread above the treeline ( $\mathrm{Sk}$ a $\mathrm{r}$ et al. 1971), the main addition of gene material to the population probably takes place from west through station $A$. If adaptations to local conditions were pronounced a clinal variation ranging from station $A$ to $D$ would be expected, and in fact the divergence between station $A$ and $B, C$ and $D$ respectively successively increased. The present study confirmed the hypothesis, that the covert variation within a bank vole population could be considerable.

Acknowledgements: I am grateful to Mr. T. Fredriksen who skinned the voles, and I also thank Mr. R. Li e for assistance with the nomenclature.

\section{REFERENCES}

1. Barrett-Hamilton G. E. H. \& Hinton M. A. C., 1913a: On a collection of mammals from the Inner Hebrides. Proc. zool. Soc. Lond., 1913: 821-839.

2. Barrett-Hamilton G. E. H. \& Hinton M. A. C., 1913b: Three new voles from the Inner Hebrides, Scotland. Ann. Mag. nat. Hist., 12: 316-368.

3. Berry R. J., 1963: Epigenetic polymorphism in wild populations of Mus musculus. Genet. Res., 4: 193-220.

4. B er r y R. J., 1970: Covert and overt variation, as exemplified by British mouse populations. Symp. zool. Soc. Lond., 26: 3-26.

5. Berry R. J., 1973: Chance and change in British long-tailed field mice (Apodemus sylvaticus). J. Zool., Lond. 170: 351-366. 
6. Berry R. J. \& J a cobsen M. E., 1975: Ecological genetics of an island population of the house mouse. J. Zool., Lond. 175: 523-540.

7. Berry R. J. \& S a rle A. G., 1963: Epigenetic polymorphism of the rodent skeleton. Proc. zool. Soc. Lond., 140: 577-615.

8. Berry R. J. \& Warwick T., 1974: Field mice (Apodemus sylvaticus) on the Castle Rock, Edinburgh: an isolated population. J. Zool., Lond. 174: 225-331 .

9. Corbet G. B., 1961: Origin of the British insular races of small mammals and of the 'Lusitanian' fauna. Nature, 191: 1037-1040.

10. Corbet G. B., 1964: Regional variation in the bank-vole Clethrionomys glareolus in the British Isles. Proc. zool. Soc. Lond., 143: 191-219.

11. Grüneberg H., 1951: The genetics of a tooth defect in the mouse. Proc. R. Soc. B, 138: $437-451$.

12. Grüneberg H., 1963: The Pathology of Development. Blackwell, Sci. Publ. $1-309+$ XIV p., Landon.

13. Haitlinger R., 1970: Morphological characters of mountain populations of Clethrionomys glareolus (Schreber, 1780) and Apodemus agrarius (Pallas, 1773). Acta theriol., 15: 269-282.

14. M c Elman J. F. \& M or ris R. D., 1977: Patterns of behaviour and outcomes of staged laboratory encounters between two vole species. Oikos, 28: 276-284.

15. Miller G. S., 1912: Catalogue of the mammals of Western Europe (Europe exclusive of Russia) in the collection of the British Museum. Trustees Brit. Mus.: 1-1019. London.

16. Munsell Color Company Incorporated., 1974: Munsell book of color. Munsell Color Co. Inc., Baltimore.

17. S e a r le A. G., 1954: Genetical studies on the skeleton of the mouse. XI. The influence of diet on variation within pure lines. J. Genet. 52: 413-424.

18. $\mathrm{S}$ jøvold T., 1977: Non-metrical divergence between skeletal populations. Ossa 4 Suppl. 1: 1-133.

19. $\mathrm{Sk}$ a r H. J., Hagen A. \& Østbye E., 1971: The bank vole (Clethrionomys glareolus (Schreber, 1780)) in South Norwegian mountain areas. Norw. J. Zool., 19: $261-266$.

20. Steven D. M., 1952: Notes on a collection of small mammals from Western Norway. Univ. Bergen Årb. Naturv. rekke, 6: 2-13.

21. Steven D. M., 1953: Recent evolution in the genus Clethrionomys. Soc. Exp. Biol. Symp., 7: 310-319.

22. Steven D. M., 1955: Untersuchungen über die britischen Formen von Clethrionomys, Z. Säugetierk., 20: 70-74.

Accepted, April 8, 1978.

Christian OTTO

WIELKOSC I ZMIENNOSC SZKIELETU U SAMCOW NORNICY RUDEJ Z ZACHODNIEJ NORWEGII W ZALEZNOSCI OD GRADIENTU WYSOKOSCI

\section{Streszczenie}

Zbadano zmienność wielkości ciała i ubarwienia futerka oraz niemetrycznych cech szkieletu u samców Clethrionomys glareoius bytujących na różnych wysoko- 
ściach n.p.m. Ciężar ciała obniża się istotnie u zwierząt odłowionych na wys. $600 \mathrm{~m}$ (stacja C) w porównaniu z niższym punktem odłowu, leżącym na wysokości $300 \mathrm{~m}$ (stacja B). Zwierzęta odłowione w stacji C charakteryzują się najszerszymi i najdłuższymi czaszkami (Tabela 2).

Cechy niemetryczne nie zmieniają się w sposób jednorodny, jak cechy metryczne (Tabela 3). To samo dotyczy cech ubarwienia. Oszacowane rozbieżności kompleksu badanych cech w czterech stacjach odłowu są najwyższe przy porównaniu materiału ze skrajnych stacji a najniższe dla danych pochodzących z stacji położonych na wysokości 600 (C) i 750 (D) m n.p.m. (Tabela 4). Wykazany stopień rozbieżności przemawia za istnieniem genetycznego zróżnicowania między demami bytującymi w badanym terenie. 